\title{
'Bing' Sweet Cherry on the Dwarfing Rootstock 'Gisela 5': Thinning Affects Fruit Quality and Vegetative Growth but not Net $\mathrm{CO}_{2}$ Exchange
}

\author{
Matthew D. Whiting 1 \\ Washington State University, Irrigated Agriculture Research and Extension Center, 24106 N. Bunn \\ Road, Prosser, WA 99350 \\ Gregory A. Lang \\ Department of Horticulture, Michigan State University, East Lansing, MI 48824-1325
}

\begin{abstract}
AdDitional INDEX wORDs. carbohydrate assimilation, fruit to leaf area ratio, photosynthesis, Prunus avium, sink strength, yield
Abstract. Canopy fruit to leaf area ratios (fruit no./m² leaf area, F:LA) of 7- and 8-year-old 'Bing' sweet cherry (Prunus avium L.) on the dwarfing rootstock 'Gisela 5' (P. cerasus L. x P. canescens $\mathrm{L}$.) were manipulated by thinning dormant fruit buds. F:LA influenced yield, fruit quality, and vegetative growth, but there were no consistent effects on whole canopy net $\mathrm{CO}_{2}$ exchange rate $\left(\mathrm{NCER}_{\text {canopy }}\right)$. Trees thinned to 20 fruit $/ \mathrm{m}^{2} \mathrm{LA}$ had yield reduced by $68 \%$ but had increased fruit weight $(+25 \%)$, firmness $(+25 \%)$, soluble solids $(+20 \%)$, and fruit diameter $(+\mathbf{1 4} \%)$, compared to unthinned trees $\left(84\right.$ fruit $\left./ \mathrm{m}^{2}\right)$. Fruit quality declined when canopy LA was $\approx 200 \mathrm{~cm}^{2} / \mathrm{fruit}$, suggesting that photoassimi-

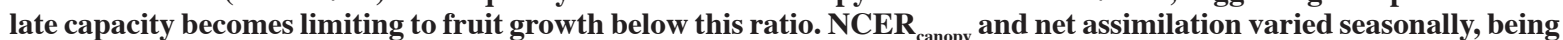
highest during stage III of fruit development (64 days after full bloom, DAFB), and falling more than $50 \%$ by 90 DAFB. Final shoot length, LA/spur, and trunk expansion were related negatively to F:LA. F:LA did not affect subsequent floral bud induction per se, but the number of flowers initiated per bud was negatively and linearly related to F:LA. Although all trees were thinned to equal floral bud levels per spur for the year following initial treatment (2001), fruit yields were highest on the trees that previously had no fruit, reflecting the increased number of flowers initiated per floral bud. Nonfruiting trees exhibited a sigmoidal pattern of shoot growth and trunk expansion, whereas fruiting trees exhibited a double sigmoidal pattern due to a growth lag during Stage III of fruit development. Vegetative growth in the second year was not related to current or previous season F:LA. We estimate that the LA on a typical spur is only sufficient to support the full growth potential of a single fruit; more heavily-set spurs require supplemental LA from nonfruiting shoots. From these studies there appears to be a hierarchy of developmental sensitivity to high F:LA for above-ground organs in 'Bing'/'Gisela 5' sweet cherry trees: trunk expansion $>$ fruit soluble solids (Stage III) $>$ fruit growth $($ Stage III) $>$ LA/spur > shoot elongation > fruit growth (Stages I and II) > LA/shoot. Current season F:LA had a greater influence on fruit quality than prior cropping history, underscoring the importance of imposing annual strategies to balance fruit number with LA.
\end{abstract}

Hybrid rootstocks for sweet cherry (Prunus avium L.) have been introduced that promote various degrees of precocity and control scion vigor (Lang, 2000; Perry et al., 1997). 'Gisela 5' ( $P$. cerasus $\mathrm{L} . \mathrm{X}$ P. canescens $\mathrm{L}$.) is one such clonal rootstock that, in the Yakima valley of Washington, induces flowering in the third leaf and reduces scion vigor by $\approx 40 \%$ compared to 'Mazzard' $(P$. avium L.). However, standard orchard management practices with these highly productive rootstocks tend to result in high yields of small fruit (Edin et al., 1996; Lang, 2000; Lang and Ophardt, 2000). Consequently, commercial adoption of such potentially advantageous rootstocks remains limited.

Crop load management by chemical or manual removal of blossoms or fruit has been shown to improve fruit quality in peach (Farley, 1923), wine grapes (Weaver and Pool, 1971), apple (Greene et al., 1990), plum (Wells and Bukovac, 1978), and oranges (Hutton, 1992). Traditionally, sweet cherry crop loads are managed indirectly, by annual pruning to control vegetative growth and thereby, future fruiting sites. There are few data that quantify the relationship between crop load and fruit quality in cherry production systems using either standard nonprecocious, vigorous rootstocks [e.g., seedlings or clonal selections of 'Mazzard' and 'Mahaleb' ( $P$. mahaleb L.)] or precocious, vigor-controlling

Received for publication 25 Oct. 2002. Accepted 15 Oct. 2003. We are grateful to Amanda Christopher and Maura Niño for their technical assistance.

'To whom reprint requests should be addressed. rootstocks. Webster and Schmidt (1996) showed that the ratio of spurs:flowers:fruit may vary from 1:9:0.3 on the vigorous F.12/1 (clonal 'Mazzard') rootstock to 1:27:10 on productive, precocious clonal rootstocks. This suggests that the reduction in fruit quality may be, at least partially, a consequence of a high ratio of fruit number to leaf area (F:LA).

Fruit number and leaf area relationships are dynamic. In apple, high crop load reduced canopy leaf area (Wünsche et al., 2000), suppressed trunk radial expansion and final shoot length (Giuliani et al., 1997a), and reduced floral bud initiation (Ryugo, 1986). In sweet cherry on vigorous rootstocks, vegetative growth decreased as crop load increased (Looney, 1989) and fruiting trees exhibited less shoot growth and leaf area than de-blossomed trees (Kappel, 1991). Roper et al. (1988) reported lower total nonstructural carbohydrates in leaves on fruiting than on nonfruiting sweet cherry. High crop load reduced fruit quality and delayed maturity (Proebsting and Mills, 1981), and increased fruit susceptibility to bruising (Spayd et al., 1986). Roper and Loescher (1987) isolated fruiting spurs by girdling and found a positive relationship between leaf area per fruit (LA:F) and fruit weight, color, and soluble solids. This artificial system indicated that spur leaves lacked the photosynthetic capacity to fully support sweet cherry fruit growth (Roper et al., 1987). However, limited research has investigated F:LA effects on canopy source-sink relations in whole sweet cherry trees on dwarfing, precocious rootstocks.

An abundance of data exists regarding the influence of crop 
load on net $\mathrm{CO}_{2}$ exchange rate (NCER) and carbon balance in apple [Malus sylvestris (L.) Mill. Var. domestica (Borkh.) Mansf.] (Flore and Lakso, 1989; Forshey and Elfving, 1989). However, most of these studies were limited to portions of individual leaves, and/or were conducted in nonorchard environments. More recently, using whole-canopy gas exchange systems, Wibbe et al. (1993) and Giuliani et al. (1997b) showed increased carbon exchange rates in fruiting vs. nonfruiting apple canopies. Wünsche et al. (2000) found a positive linear trend between whole-canopy gas exchange and apple crop load. In addition, Giuliani et al. (1997b) showed that canopy conductance was higher in a fruiting vs. nonfruiting apple canopy.

No reports were found which examined the relationship between F:LA and NCER in stone fruit at the canopy scale, although experiments have compared NCER of single leaves on fruiting vs. nonfruiting trees (DeJong, 1986; Roper et al., 1988). DeJong (1986) showed that single leaf $\mathrm{CO}_{2}$ assimilation rates were $11 \%$ to $15 \%$ higher in fruiting vs. nonfruiting peach (P. persica Batsch.) trees near the beginning of stage III of fruit development. In addition, Ben-Mimoun et al. (1996) reported a positive effect of fruit demand on peach leaf photosynthesis. Roper et al. (1988) found no difference in NCER throughout fruit development comparing single leaves on 2-year-old spurs of fruiting vs. nonfruiting sweet cherry trees. Similarly, Sams and Flore (1983) found no consistent effect of fruit on sour cherry $(P$. cerasus L.) leaf NCER. Moreover, these experiments (Roper et al., 1988; Sams and Flore, 1983) examined carbon exchange of cherry trees with vigorous seedling rootstocks; therefore, nothing is known about cherry NCER on dwarfing, precocious rootstocks which may alter typical carbon partitioning.

The objective of this research was to study effects of variations in F:LA on vegetative and reproductive growth and the efficiency of canopy NCER in sweet cherry on 'Gisela 5' rootstocks.

\section{Materials and Methods}

Plant material and experimental design. 'Bing'/'Gisela 5' sweet cherry trees, planted in Spring 1995 and spaced $2.5 \times 5.0$ $\mathrm{m}$ in north-south rows, were trained to a free-standing, standard multiple-leader, open-center architecture at Washington State University's Roza research orchard, Prosser, Wash. $\left(46.2^{\circ} \mathrm{N}\right.$, $\left.119.7^{\circ} \mathrm{W}\right)$. The soil was a silty loam and trees were irrigated with under-tree microsprinklers. By Spring 2000, trees had just filled their allotted space.

Nine experimental trees were selected on the basis of uniform vigor and canopy architecture, and were assigned to a randomized complete block design of three blocks (orchard location) and three single tree treatments per block. Treatment means were compared using SAS software (ProcGLM). Regression analysis was used to determine the relationship between vegetative growth parameters and time or canopy F:LA.

Crop manipulation treatments imposed 31 Mar. 2000 consisted of a control (no manipulation, C), removal of all but one flower bud per spur (thinned, T), and complete removal of all flower buds (no fruit, NF). To study the subsequent effects of the first year (2000) fruiting levels on return fruiting and growth, in February 2001 all trees were thinned (-T) to two flower buds per spur. The second year (2001) treatments are designated as C-T, T-T, and NF-T, respectively. Standard orchard management practices (irrigation, fertilization, pest control, and dormant pruning) were followed in both years.

Vegetative CHARACTERISTics. Shoot length was measured in 2000 and 2001 from 25 randomly selected shoots per tree at $\approx 14 \mathrm{~d}$ intervals from shortly after budbreak until the cessation of growth. Trunk diameter at $20 \mathrm{~cm}$ above the graft union was measured at a similar interval and used to estimate trunk crosssectional area (TCSA). Whole-canopy leaf area $\left(\mathrm{LA}_{\text {tree }}\right)$ was estimated nondestructively at 10 to $14 \mathrm{~d}$ intervals as the sum of spur and shoot LA. The LA of 20 randomly selected spurs per tree was determined by an area meter (CI-203, CID Inc., Vancouver, Wash.) and used to estimate spur LA per tree [LA $\mathrm{LAu}_{\text {spu }}$ (no. spurs per tree $) \times($ mean LA per spur)]. The relationship between shoot length and shoot LA was established from 10 randomly selected shoots per tree, and used to estimate shoot LA per tree $\left(\mathrm{LA}_{\text {shoot }}\right.$; [mean shoot length] $\times$ [number of shoots per canopy $] \times[$ leaf area per unit shoot length]).

TREe Light INTERCEPTION. The percent of photosynthetically active radiation $(P A R)$ intercepted by the canopy was determined at full canopy by the ceptometer (AccuPar PAR-80, Decagon Devices, Pullman, Wash.) technique outlined in Wünsche et al. (1995). Values of below-canopy irradiance recorded in a grid pattern were compared to simultaneously measured above-canopy values at three times during the day: 2 to $3 \mathrm{~h}$ before solar noon, within $1 \mathrm{~h}$ of solar noon, and 2 to $3 \mathrm{~h}$ after solar noon.

YIELD AND FRUIT QUALITY. Fruit number and yield per tree were recorded at harvest (27 June 2000, $74 \mathrm{~d}$ after full bloom [DAFB]; and 25 June 2001, 73 DAFB). From each tree, 100 randomly sampled fruit were evaluated at room temperature for row-size (an industry sales designation), mass, firmness (Firmtech, BioWorks Inc., Stillwater, Okla.), and soluble solids. Weighted fruit diameter was calculated as the sum of the products of fruit diameter $(\mathrm{mm})$ and the percent of harvested fruit in that diameter category.

Single-LeAf GAS EXCHANGE. From each replicate tree, six or seven subsample $2.5 \mathrm{~cm}^{2}$-portions of fully expanded and sunexposed spur and shoot leaves (total of 40 leaves per treatment) were enclosed within a broadleaf cuvette (PPSystems, Haverhill, Mass.) connected to a gas analyzer (TPS-1,PPSystems, Haverhill, Mass.) within $1 \mathrm{~h}$ of solar noon. Measurements were recorded under saturating irradiance $\left(\geq 1000 \mu \mathrm{mols} \cdot \mathrm{m}^{-2} \cdot \mathrm{s}^{-1} P A R\right)$ and leaf temperature of 25 to $30^{\circ} \mathrm{C}$. Leaf net $\mathrm{CO}_{2}$ exchange rate $\left(\mathrm{NCER}_{\text {leaf }}\right)$ was recorded within one min of leaf enclosure.

WHOLE-CANOPY GAS EXCHANGE. Whole-canopy NCER (NCERcanopy) was estimated from recorded $\mathrm{CO}_{2}$ differentials (i.e., chamber inlet minus outlet) using an automated gas exchange system and a set of three inflatable Mylar cuvettes similar to that described in Whiting and Lang (2001). Cuvette dimensions were $2.5 \times 5.5 \mathrm{~m}$ (diameter $\times$ height). The plenum base was constructed of 0.006 $\mathrm{mm}$ polyethylene and the inner, middle, and outer air dispersal rings had 8,17 , and 25 apertures ( $9 \mathrm{~cm}$ diameter), respectively, resulting in a total inlet area of $0.318 \mathrm{~m}^{2}$. Outlet gases were drawn continuously from each cuvette at $175 \mathrm{~cm}^{3} \cdot \mathrm{s}^{-1}$ via high density polyethylene tubing $\left(0.6 \mathrm{~cm}^{2}\right.$ i.d. $)$ under negative pressure from a vacuum pump (model 79202-00; Cole Parmer, Vernon Hills, Ill.). Switching among cuvettes was achieved by solenoid valves controlled by a datalogger (CR10x; Campbell Scientific, Logan, Utah). Inlet and outlet gases were monitored (TPS-1, PP Systems, Haverhill, Mass.) continuously over a 24-h period for each measurement date and $\left[\mathrm{CO}_{2}\right]$ data were downloaded directly to a portable computer in the orchard. Ambient PAR, air temperature, and inlet air velocity for each chamber were measured continuously and logged at 1 min intervals. Canopy gas exchange data were collected on one block per sample date. Daily NCER $_{\text {canopy }}$ was estimated from the diurnal NCER curves following the method of Long and Hällgren (1985). 
Table 1. Effect of thinning (imposed 30 Apr. 2000) on fruit yield and quality of 7- and 8-year-old 'Bing'/Gisela 5 sweet cherry trees at harvest during A) year of treatment (2000) and B) the subsequent season (2001; flower bud densities were equalized across previous year treatments at 2 buds/spur). Harvest $2000=74$ DAFB; harvest $2001=73$ DAFB. $n=3$.

\begin{tabular}{|c|c|c|c|c|c|c|c|}
\hline Treatment & $\begin{array}{c}\text { Yield } \\
(\mathrm{kg} / \text { tree })\end{array}$ & $\begin{array}{c}\text { Fruit } \\
\text { (no./tree) }\end{array}$ & $\begin{array}{l}\text { Fruit:leaf area } \\
\left(\text { no. } / \mathrm{m}^{2}\right)\end{array}$ & $\begin{array}{c}\text { Fruit wt } \\
\qquad(\mathrm{g})\end{array}$ & $\begin{array}{c}\text { Soluble solids } \\
\text { (\%) }\end{array}$ & $\begin{array}{l}\text { Fruit diam } \\
\qquad(\mathrm{mm})\end{array}$ & $\begin{array}{l}\text { Firmness } \\
\left(\mathrm{g} \cdot \mathrm{mm}^{-1}\right)\end{array}$ \\
\hline \multicolumn{8}{|l|}{2000} \\
\hline Control (C) & 23.7 & 3081 & 84 & 7.7 & 21.2 & 24.8 & 281 \\
\hline Thinned (T) & 7.6 & 819 & 20 & 9.6 & 25.4 & 28.0 & 352 \\
\hline No fruit (NF) & 0 & 0 & 0 & --- & --- & --- & --- \\
\hline $\operatorname{LSD}_{0.05}$ & 5.4 & 446 & 23.1 & 1.2 & 2.5 & 1.8 & 66.1 \\
\hline \multicolumn{8}{|l|}{2001} \\
\hline $\mathrm{C}-\mathrm{T}$ & 33.4 & 4425 & 118 & 7.5 & 20.4 & 25.2 & 305 \\
\hline $\mathrm{T}-\mathrm{T}$ & 32.1 & 4897 & 129 & 6.7 & 19.2 & 24.3 & 275 \\
\hline $\mathrm{NF}-\mathrm{T}$ & 35.2 & 5920 & 149 & 6.0 & 18.7 & 25.6 & 273 \\
\hline $\mathrm{LSD}_{0.05}$ & NS & NS & NS & NS & 1.1 & NS & NS \\
\hline
\end{tabular}

\section{Results and Discussion}

ThinNING EFFECTS ON F:LA AND FRUIT QUALITY. In 2000, stages I, II and III of fruit growth occurred from $\approx 1$ to 31 DAFB (15 Apr. to 15 May), 32 to 45 DAFB (16 to 29 May), and 46 to 73 DAFB (30 May to harvest on 27 June), respectively. Flower bud removal affected F:LA, yield, and fruit quality (Table 1). Compared to C, T trees had $\approx 76 \%$ lower F:LA, 74\% fewer fruit, $68 \%$ lower yields, and $67 \%$ lower yield efficiency ( $\mathrm{kg}$ of fruit per $\mathrm{cm}^{2} \mathrm{TCSA}$ ), (data not presented). However, thinning improved fruit quality. Fruit from thinned trees were $\approx 25 \%$ heavier, had $20 \%$ higher soluble solids, $25 \%$ greater firmness, and $315 \%$ more fruit in the large size categories ( $\geq 26.6 \mathrm{~mm}$ ) (Fig. 1A). Mean weighted diameter was $24.8 \mathrm{~mm}$ for $\mathrm{C}$ fruit and $28.0 \mathrm{~mm}$ for $\mathrm{T}$ fruit.

Thinning did not affect floral bud induction (Fig. 2). However, the number of floral meristems per flower bud was related negatively and linearly to previous year F:LA. This may have been a hormonal effect or a carbohydrate supply limitation during reproductive bud development. Flower bud induction in sweet cherry occurs during stage II of fruit development, a period of low reproductive and high vegetative sink activity, whereas floral meristem initiation does not occur until after harvest (Guimond et al., 1998). It has been suggested that a strong inverse relationship exists between flower formation and vigor, with vegetative bud development having precedence over that of reproductive buds under conditions of high vigor (Flore and Layne, 1999). However, in 'Bing'/'Gisela 5' trees, neither flower bud formation nor floral meristem initiation was related to shoot growth. This illustrates a slight biennial characteristic of sweet cherry reproductive physiology, but overall a consistent annual cropping potential on 'Gisela' rootstocks.

All treatment yields, fruit no./tree, and F:LA were higher in 2001 than the highest 2000 crop load, despite uniform bud thinning in 2001. Consequently, there were no significant 2000-imposed thinning treatment effects on 2001 yield, fruit no., F:LA, fruit weight, firmness (Table 1) or percent large fruit in 2001 (Fig. 1B), other than soluble solids being $6 \%$ and $9 \%$ higher in C-T than in T-T and N-T fruit, respectively. Fruit size distribution of all treatments in 2001 was similar to that of $\mathrm{C}$ trees, with fruit in the smallest category ranging from $35 \%$ to $70 \%$ (Fig. 1B). The distribution of fruit size was best in C-T trees and worst in NF-T trees, with mean weighted fruit diameters of $25.2 \mathrm{~mm}$ for C-T, $24.3 \mathrm{~mm}$ for T-T, and $23.6 \mathrm{~mm}$ for NF-T.

The smaller fruit in the second year (2001) further supports the F:LA relationships found in the first year (2000). When data were pooled from both years and all fruiting levels, a negative linear relationship existed between fruit weight and F:LA (Fig. 3A). A negative curvilinear relationship existed between fruit soluble solids or diameter and F:LA (Fig. 3B and C). Such relationships exist in many other tree fruit species, including apple (Haller and Magness, 1925) and peach (Farley, 1923; Weinberger, 1931), reflecting increased competition for photoassimilates in more heavily-cropped trees. When expressed as the inverse ratio LA: $\mathrm{F}$, fruit weight, soluble solids and diameter each increased rapidly with increasing LA:F, up to an asymptote of $\approx 200 \mathrm{~cm}^{2} \mathrm{LA} /$ fruit
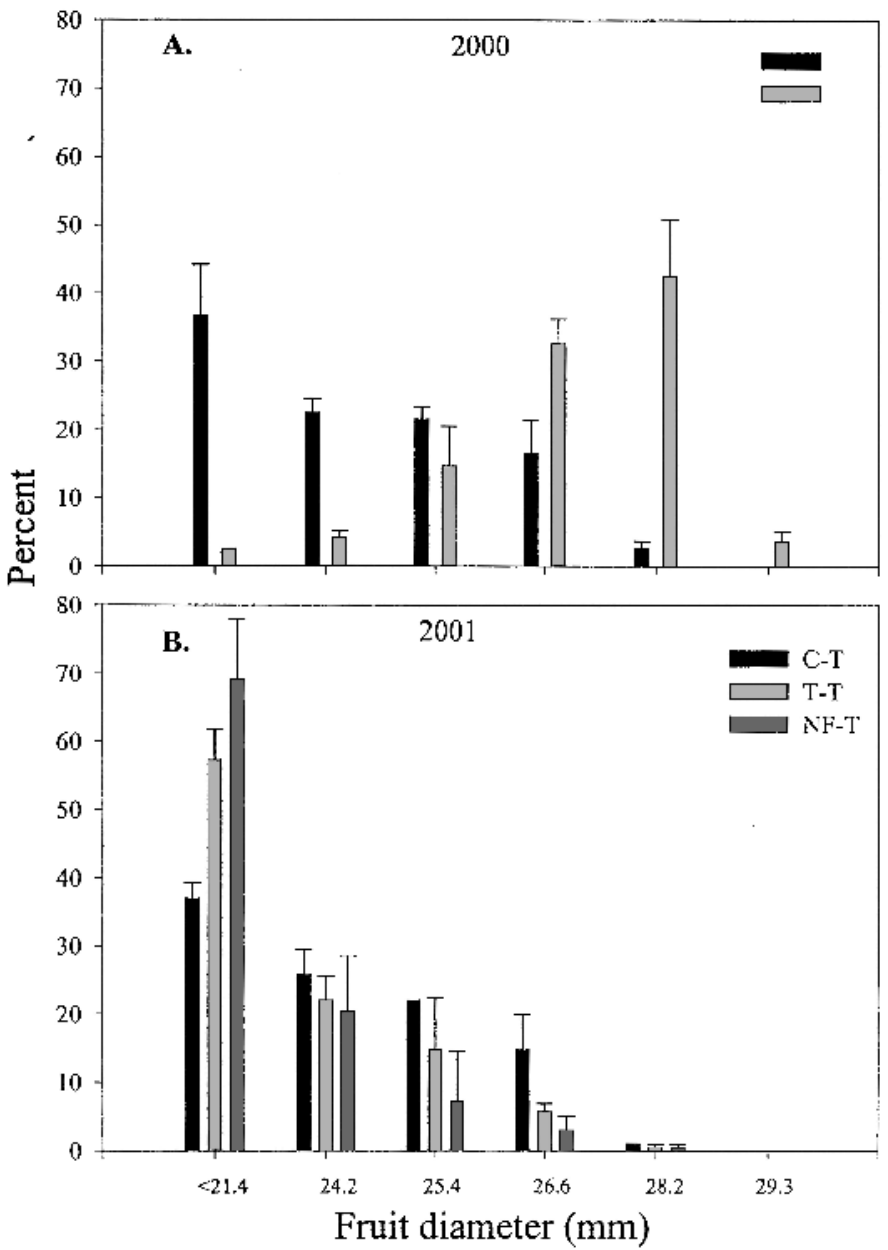

Fig. 1. Distribution of 'Bing' fruit equatorial diameter $(\mathrm{mm})$ by treatment $(\mathrm{n}=3)$ in A) 2000 (harvested 27 June, 74 DAFB) and B) 2001 (harvested 25 June, 73 $\mathrm{DAFB})$. Each bar is the treatment mean $\pm \mathrm{SE}$. Mean fruit-to-leaf area ratio in 2000: $\mathrm{C}=84, \mathrm{~T}=20$; in 2001: $\mathrm{C}-\mathrm{T}=118, \mathrm{~T}-\mathrm{T}=129, \mathrm{NF}-\mathrm{T}=149$. 


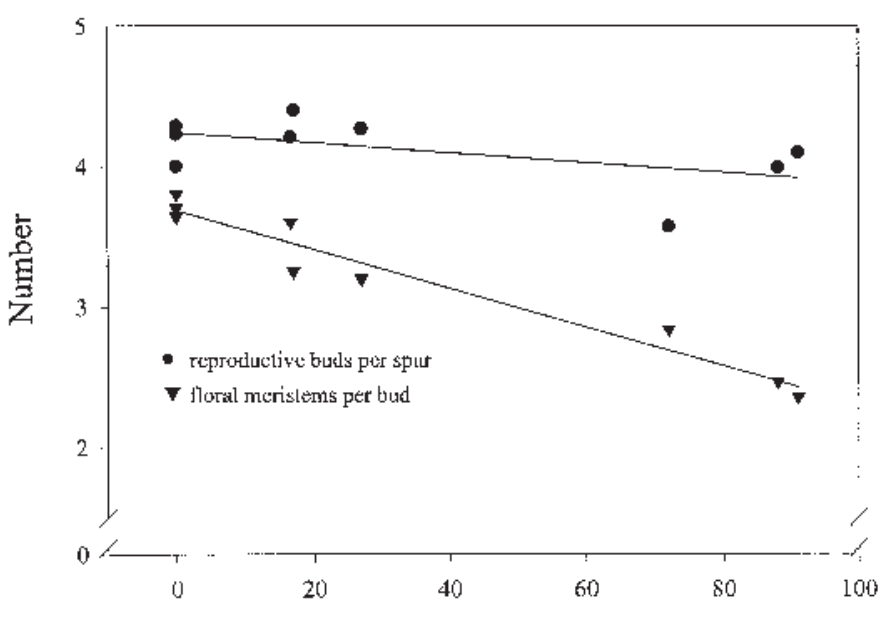

$\mathrm{F}: \mathrm{LA}\left(\mathrm{no} \cdot / \mathrm{m}^{2}\right)$

Fig. 2. Effect of 2000 fruit-to-leaf area ratio (F:LA; no. $\left./ \mathrm{m}^{2}\right)$ on 2001 flower bud formation in 'Bing'/'Gisela 5' sweet cherry trees. $\mathbf{O}=$ reproductive buds per spur; $\mathrm{y}=4.24-0.0024 \mathrm{x}, r^{2}=0.31, p<0.12$. $\boldsymbol{\nabla}=$ number of floral meristems per reproductive bud; $\mathrm{y}=3.68-0.014 \mathrm{x}, r^{2}=0.95, p<0.0001 . \mathrm{n}=3$

(Fig. 3D-F). A similar threshold was reported for individual sweet cherry spurs on trees with 'Mazzard' rootstock (Roper et al., 1987). The reduction in fruit weight, soluble solids, and diameter at a gross canopy LA:F $\leq 200$ suggests that capacity to supply or partition assimilates to fruit is limiting (i.e., source limiting condition).

Low fruit weight and small diameter from C trees in 2000 and all treatments in 2001 indicates that some type of crop load management, other than that achieved inadvertently via dormant pruning for light distribution and/or vigor control, is necessary to improve fruit quality of 'Bing'/'Gisela 5' trees. The relationships between F:LA and fruit quality (Fig. 3A-C) predict that the removal of $\approx 33$ fruit $/ \mathrm{m}^{2}$ LA (i.e., 1320 fruit/tree) would increase fruit weight $10 \%$. Similarly, to increase fruit soluble solids and mean diameter $10 \%$, crop load management strategies should remove $\approx 26$ and $\approx 45$ fruit $/ \mathrm{m}^{2} \mathrm{LA}$, respectively (i.e., 1040 to 1800 fruit/tree). Therefore, the relative developmental sensitivity of fruit quality indices to F:LA is soluble solids $>$ fruit weight $>$ fruit diameter. Roper and Loescher (1987) also reported that fruit soluble solids was more sensitive than fruit weight to varying LA:F. Thus we suggest that fruit soluble solids are most dependent upon the partitioning of current season photosynthate to fruit,

Fig. 3. Effect of (A-C) fruit-to-leaf area ratio (F:LA; no. $\left./ \mathrm{m}^{2}\right)$ or (D-F) leaf area-to-fruit ratio (LA:F; $\mathrm{cm}^{2} /$ fruit) of 7- and 8-year-old 'Bing'/“Gisela 5' sweet cherry trees on fruit (A and $\mathbf{D})$ weight, (B and $\mathbf{E})$ soluble solids, and $(\mathbf{C}$ and $\mathbf{F})$ equatorial diameter. $\mathbf{A}: \mathrm{y}=9.96-0.02 \mathrm{x}, r^{2}$ $=0.88, p<0.0001$. B: $\mathrm{y}=26.76-0.08 \mathrm{x}+0.0002 \mathrm{x}^{2}, r^{2}$ $=0.84, p<0.0004 . \mathbf{C}: \mathrm{y}=28.83-0.053 \mathrm{x}+0.0001 \mathrm{x}^{2}$, $\mathrm{r}^{2}=0.8, p<0.0012 . \mathbf{D}: \mathrm{y}=(10.4 * \mathrm{x}) /(41.7+\mathrm{x}), r^{2}=$ $0.86, p<0.0001 . \mathbf{E}: \mathrm{y}=(26.49 * \mathrm{x}) /(27.79+\mathrm{x}), r^{2}=$ $0.84, p<0.0001 . \mathbf{F}: \mathrm{y}=1755.9 \mathrm{x}^{0.075}, r^{2}=0.82, p<$ $0.0001 . \mathrm{n}=3$ because levels increase rapidly during stage III (Proebsting and Mills, 1981).

ThINNING EFFECTS ON VEGETATIVE GROWTH. In 2000, F:LA had little effect on canopy light interception, $\mathrm{LA}_{\text {tree }}$, or LA/shoot (data not presented). However, high F:LA reduced final shoot length, but not $\mathrm{LA}_{\text {shoot }}$. By contrast, high F:LA reduced LA/spur by as much as $13 \%$. For an average spur LA of $27 \mathrm{~cm}^{2}$, this would have a functional impact of about one less leaf per spur on $\mathrm{C}$ than on NF trees.

Shoot growth rates were similar among treatments during fruit growth stages I and II (Fig. 4). This suggests that during the initial 40 to $50 \mathrm{~d}$ of the growing season, assimilate partitioning to shoots was not affected by F:LA. The supply of growth resources from storage reserves and current season carbohydrates may be sufficient during early vegetative and reproductive organ growth to meet all demands. Shoot elongation rates were highest near the onset of stage III in fruiting treatments $\mathrm{C}$ and $\mathrm{T}$ (49 DAFB), and at 60 DAFB in NF (Fig. 4). During stage III, shoot elongation slowed in $\mathrm{C}$ and $\mathrm{T}$ trees compared to NF trees, indicating competition for photoassimilates between fruits and shoots. Similar results have been found in sweet cherry on 'Mazzard' (Kappel, 1991), as well as in apple (Maggs, 1963) and peach (Miller and Walsh, 1988). Stage III has been identified as the period of greatest fruit sink strength in sweet cherry (Flore and Layne, 1999; Roper et al., 1988).

Between 60 and 80 DAFB, all shoot elongation rates declined rapidly, with $\approx 85 \%$ of final shoot length completed by harvest (Fig. 4B). Just before harvest, shoot growth rates were reduced

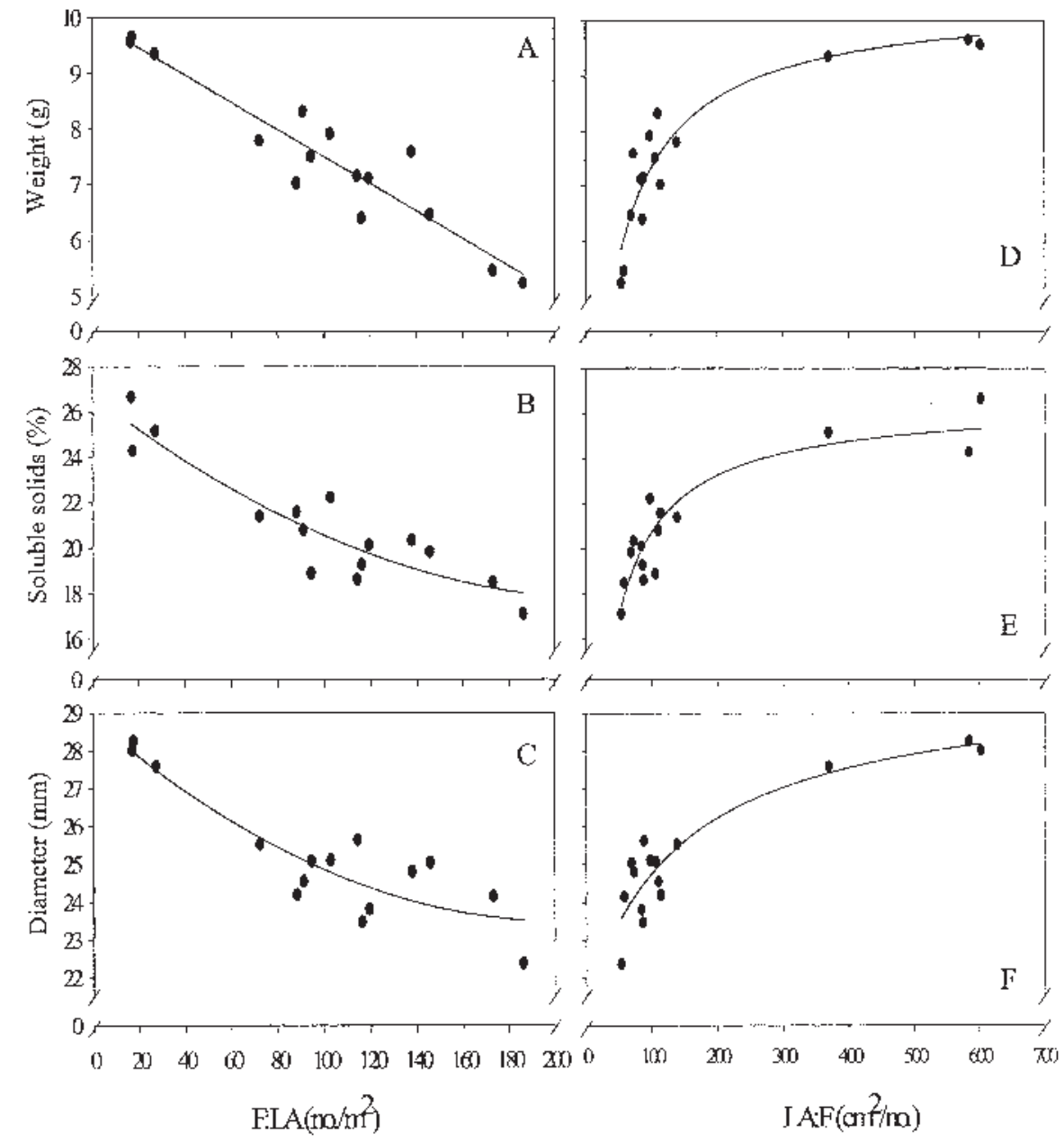


$\approx 15 \%$ and $5 \%$ in $\mathrm{C}$ and $\mathrm{T}$ trees vs. NF trees, respectively; mean absolute growth rates were $0.62,0.69$, and $0.73 \mathrm{~cm} / \mathrm{d}$ for $\mathrm{C}, \mathrm{T}$, and $\mathrm{NF}$, respectively. After harvest, absolute growth rates declined across all treatments by $\approx 86 \%$ to $0.10,0.09$, and $0.10 \mathrm{~cm}^{\cdot} \cdot \mathrm{d}^{-1}$ for $\mathrm{C}, \mathrm{T}$, and NF, respectively. In the fruiting treatments, there was a small increase in postharvest shoot growth rates about 90 to 100 DAFB, thus compensating somewhat for lower preharvest rates. As a result, final shoot lengths were $12.3 \%$ and $3.3 \%$ less for $\mathrm{C}$ and $\mathrm{T}$, respectively, than for $\mathrm{NF}$, and statistically similar.

Between 1 May 2000 and 20 January 2001, TCSA increased by $21 \%, 25 \%$, and $32 \%$ for $\mathrm{C}, \mathrm{T}$, and NF, respectively (Fig. 5 ). Preharvest mean expansion rates were 0.09 for $\mathrm{C}, 0.16$ for $\mathrm{T}$, and $0.33 \mathrm{~cm}^{2 \cdot} \mathrm{d}^{-1}$ for NF. At harvest, $\approx 39 \%$ of seasonal trunk expansion was complete, irrespective of treatment. Treatment differences became evident during stage III of fruit development, when trunk expansion rates fell to $0.02 \mathrm{~cm}^{2 \cdot} \mathrm{d}^{-1}$ for $\mathrm{C}$ and 0.07 $\mathrm{cm}^{2} \cdot \mathrm{d}^{-1}$ for $\mathrm{T}$ compared to 0.38 for NF. However, rate of trunk expansion increased immediately after harvest for $\mathrm{C}$ and $\mathrm{T}$ and declined in NF trees (Fig. 5).

These data suggest that cambial meristems are not strong sinks in sweet cherry trees. Trunk expansion was reduced to a greater extent by fruiting than was shoot elongation, and nearly was inhibited completely during maximum fruit and vegetative sink demand (Fig. 5). Similar results have been reported in apple (Giuliani et al., 1997a) and peach (DeJong and Grossman, 1994).
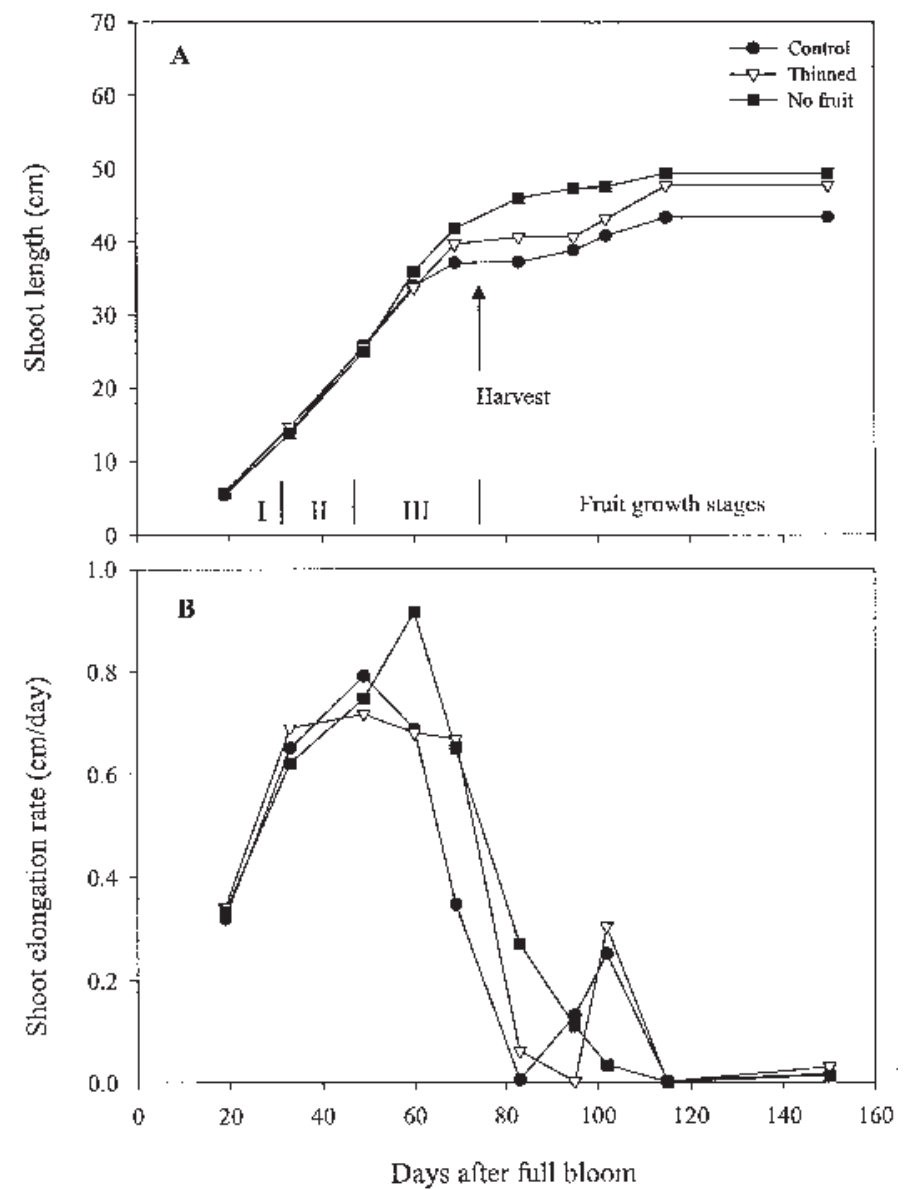

Fig., 4. Seasonal trend of (A) shoot length, and (B) absolute shoot elongation rate as affected by canopy fruit to leaf area ratio (F:LA) in 7-year-old 'Bing'/'Gisela 5 ' sweet cherry trees in 2000. Mean F:LA $\left(\right.$ no. $\left./ \mathrm{m}^{2}\right)$ : control $=84$, thinned $=20$, no fruit $=0$. Legend in $\mathbf{A}$ applies to $\mathbf{B}$. Stages of fruit development are indicated in A. Full bloom $=14$ April. Harvest $=27$ June $(74$ DAFB $) . n=3$.
In addition, trunk expansion rates increased to a maximum immediately following harvest in fruiting treatments, suggesting that trunk expansion is highly sensitive to competition from alternative sinks. This F:LA effect suggests that the use of yield efficiencies based upon TCSA (i.e., $\mathrm{kg}$ fruit $/ \mathrm{cm}^{2}$ ) for comparative germplasm evaluations may be misleading without reference to this potentially confounding factor.

In 2001, the higher F:LA across all treatments reduced shoot length, LA/spur, and $\mathrm{LA}_{\text {spur }}$, compared to 2000 (data not shown). Thus, the effects of different F:LA across years were consistent with the within-year effects of the imposed thinning treatments. Across both years, LA/spur was related negatively and linearly to F:LA (Fig. 6A) and the relationship between shoot length and F:LA was negative and curvilinear (Fig. 6B). In 2001, $\mathrm{LA}_{\text {tree }}$ and spur no./tree were similar to 2000 across all treatments, but 2001 canopies were comprised of a higher number of shoots, greater $\mathrm{LA} /$ shoot, and greater $\mathrm{LA}_{\text {shoot }}$. This suggests that, while the trees had filled their orchard space by 2000 , significant structural changes occurred within the canopy in 2001 that increased shoot number, presumably due to increased dormant heading cuts to contain the canopy in its allotted space and the rise of lateral shoots along previously spur-dominated branches.

Inherent variability in number of spurs and shoots among trees, and the small sample size $(n=9)$, may account for the lack of a statistically significant F:LA effect upon $\mathrm{LA}_{\text {tree }}$ in either year. $\mathrm{LA}_{\text {tree }}$ and dry weight accumulation were reduced in fruiting vs. nonfruiting 7-year-old 'Lambert' sweet cherry trees on 'Mazzard' rootstocks (Kappel, 1991). In comparison, the effect of fruiting on $\mathrm{LA}_{\text {tree }}$ has been inconsistent in apple. Wünsche et al. (2000)
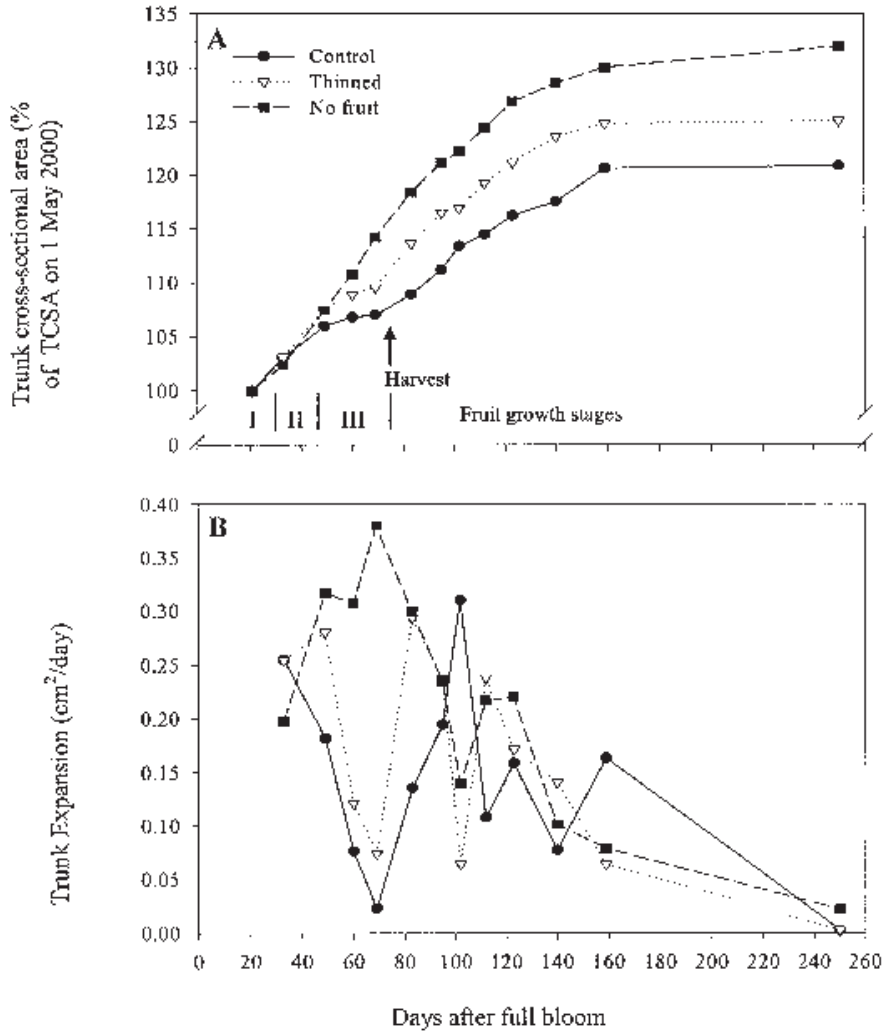

Fig. 5. Seasonal trend of (A) trunk cross-sectional area (TCSA) increment (as \% of TCSA on 1 May 2000), and (B) absolute trunk expansion rate, as affected by canopy fruit to leaf area ratio (F:LA) in 7-year-old 'Bing'/'Gisela 5' sweet cherry trees in 2000. Mean F:LA $\left(\right.$ no. $\left./ \mathrm{m}^{2}\right)$ : control $=84$, thinned $=20$, no fruit $=0$. Legend in $\mathbf{A}$ applies to $\mathbf{B}$. Stages of fruit development are indicated in $\mathbf{A}$. Full bloom $=14$ April. Harvest $=27$ June $(74$ DAFB $) . n=3$. 

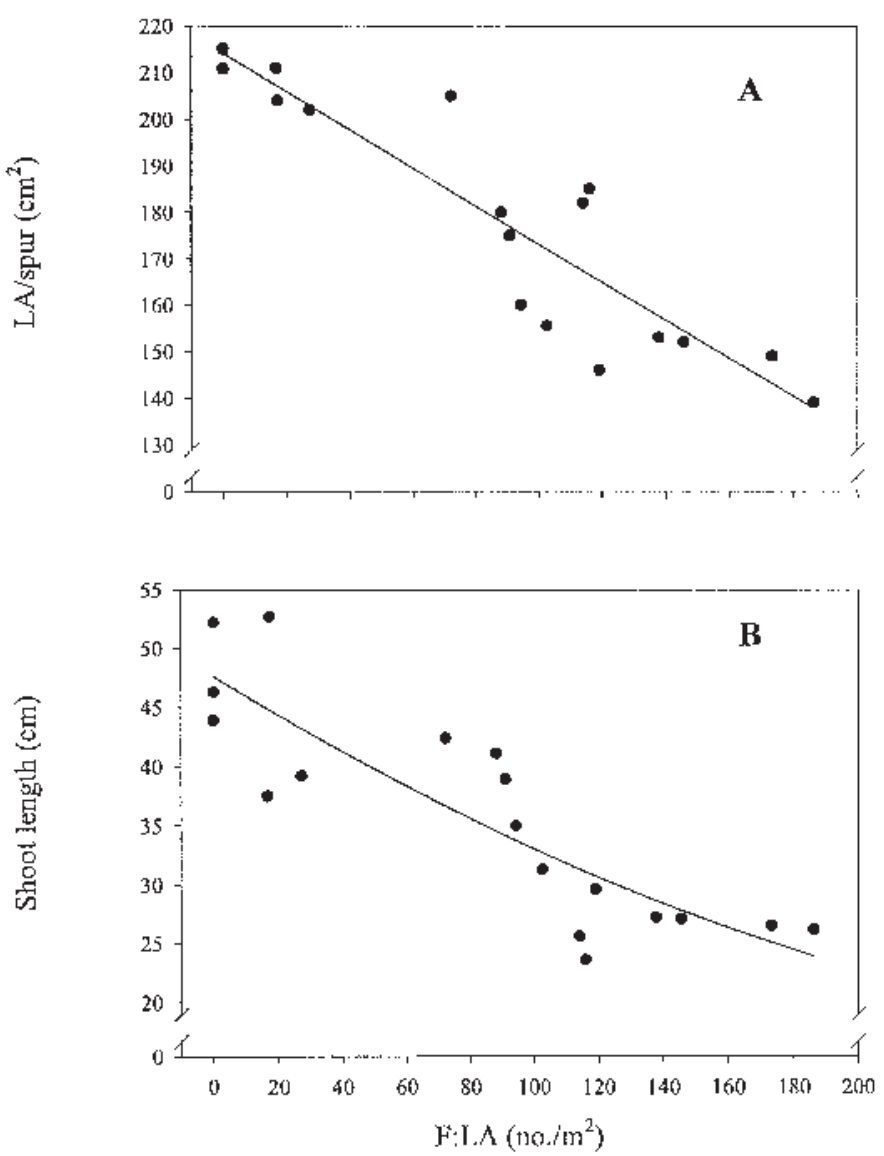

Fig. 6. Effect of fruit-to-leaf area ratio (F:LA; no./m²) on (A) spur leaf area $\left(\mathrm{cm}^{2}\right)$ at full expansion (29 May in both years) and (B) final shoot length in 7- and 8year-old 'Bing'/'Gisela 5' sweet cherry trees. A: $\mathrm{y}=214.14-0.41 \mathrm{x}, r^{2}=0.84$, $p \leq 0.0001 ; \mathbf{B}: \mathrm{y}=47.62-0.167 \mathrm{x}+0.0002 \mathrm{x}^{2}, r^{2}=0.75, p<0.0011 . \mathrm{n}=3$.

reported reduced LA on fruiting trees compared to nonfruiting, while Palmer et al. (1997) and Wibbe et al. (1993) reported no relationship between fruiting and LA.

The largest proportional reductions in apple tree growth due to fruiting may occur in the root system (Maggs, 1963). However, Flore and Layne (1999) have reported that roots account for very little of annual dry weight increment in mature, fruiting

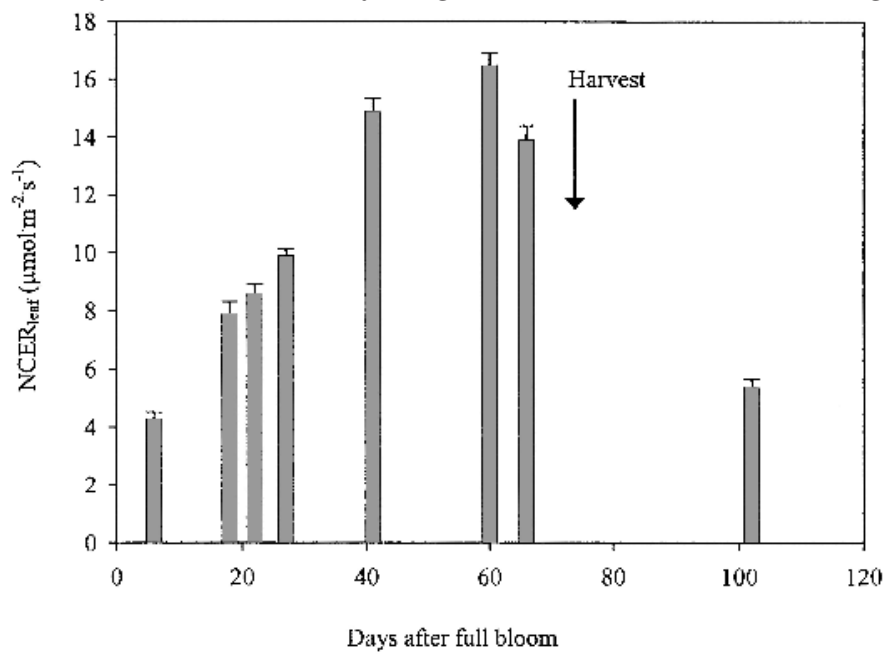

Fig. 7. Seasonal trend of light-saturated single-leaf net $\mathrm{CO}_{2}$ exchange rate of thinned (20 fruit $/ \mathrm{m}^{2}$ leaf area) 7-year-old 'Bing'/'Gisela 5' sweet cherry trees. Each bar is the mean of 40 leaves $\pm \mathrm{SE}, \mathrm{n}=3$. cherry trees. Because F:LA effects on the root system were not investigated in this study, our results suggest that the relative developmental sensitivity of above-ground vegetative organs to F:LA in 'Bing'/'Gisela 5' sweet cherry trees is: trunk expansion $>\mathrm{LA}_{\text {spur }}>$ shoot elongation $>\mathrm{LA}_{\text {shoot }}$.

THINNING EFFECTS ON LEAF GAS EXCHANGE. There were no differences in $\mathrm{NCER}_{\text {leaf }}$ among thinning treatments (data not shown). During early stage I (6 DAFB), light-saturated NCER leaf $_{\text {was only }}$ $26 \%$ of the seasonal maximum (Fig. 7). Relatively low NCER at this stage may have been due to incomplete development of photosynthetic competency, immature stomatal development (Sams and Flore, 1982), or incomplete vascular connections and inability to export photosynthate (Giaquinta, 1978). NCERleaf doubled within $14 \mathrm{~d}$, during late stage I, reaching 8.6 to 9.9 $\mu \mathrm{mol} \cdot \mathrm{m}^{-2} \cdot \mathrm{s}^{-1}$. NCER $\mathrm{Neaf}_{\text {lea }}$ continued to increase during stage II and reached a maximum of $16.5 \mu \mathrm{mol} \cdot \mathrm{m}^{-2} \cdot \mathrm{s}^{-1}$ in stage III, $\approx 1$ week before harvest. Thereafter, through 25 July, NCER leaf $_{\text {dropped }}$ $\approx 67 \%$.

The seasonal trend in midday light-saturated $\mathrm{NCER}_{\text {leaf }}$ (Fig. 7) reflects changes in leaf phenology, vegetative and reproductive sink demand, and environmental conditions. Roper and Kennedy (1986) showed that leaf stomatal conductance and photosynthetic efficiency increased rapidly with expansion and were highest before full expansion. Similar relationships have been reported during leaf development in apple (Kennedy and Johnson, 1981) and sour cherry (Sams and Flore, 1982). Roper et al. (1988) reported a similar seasonal trend in leaf net photosynthesis, with maximum rates occurring during stage III, the period of maximum stone fruit sink demand (DeJong and Grossman, 1994; Flore and Layne, 1999) and maximum cherry shoot elongation rate.

ThinNing EFFECTS ON CANOPY GAS EXChANGE. Diurnal curves

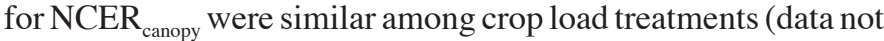
shown; see Whiting, 2001). On a leaf area basis, daily NCER was much lower than NCER leaf $_{\text {. }}$ Regardless of F:LA, NCER canopy $^{\text {canopy }}$ values were highest at $64 \mathrm{DAFB}$, declined rapidly between 76 and $90 \mathrm{DAFB}$, and continued to decline less dramatically thereafter (Fig. 8A). The period of maximum photosynthetic rate coincides closely with maximum shoot growth rates and stage III of fruit development. Chalmers et al. (1975) showed that $\mathrm{CO}_{2}$ assimilation efficiency in peach nearly doubled between stages II and III of fruit development, and was reduced by $33 \%$ following harvest. In addition, Gucci et al. (1995) reported that a 47\% reduction in sweet cherry $\mathrm{NCER}_{\text {leaf }}$ occurred within $24 \mathrm{~h}$ of fruit removal. In our study, sweet cherry NCER canopy $_{\text {and net assimilation declined }}$ $\approx 47 \%$ between 76 and 90 DAFB, despite similar environmental conditions on these dates. This suggests that remaining carbohydrate sinks (e.g., cambial meristems and root growth) are not comparably strong. By 155 DAFB, mean diurnal NCER $_{\text {canopy }}$ was $<1 \mu \mathrm{mol} \cdot \mathrm{m}^{-2} \cdot \mathrm{s}^{-1}$ in all trees, although net assimilation was still positive. However, by this time the trees had begun to show early signs of senescence (e.g., leaf yellowing and $\approx 5 \%$ leaf drop).

Midday $\mathrm{NCER}_{\text {leaf }}$ values (Fig. 7) were, on average, $26 \%$ to $50 \%$ higher than NCER canopy $_{\text {at }}$ similar dates and times, before harvest. Seasonally, however, NCER $_{\text {canopy }}$ varied similarly to NCER $_{\text {leaf }}$ (Fig. 8A). Previous analyses of sweet cherry NCER also have indicated that $\mathrm{NCER}_{\text {leaf }}$ values are significantly higher than $\mathrm{NCER}_{\text {canopy }}$ (Whiting and Lang, 2001), and similar results have been reported in apple (Wünsche and Palmer, 1997) and grape (Poni et al., 1997). This is due to reduced light in the canopy interior and greater respiratory $\mathrm{CO}_{2}$ efflux, particularly when com-

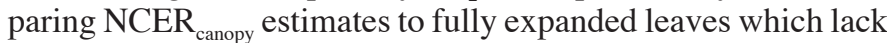
a growth respiration component (DeJong and Grossman, 1994). 

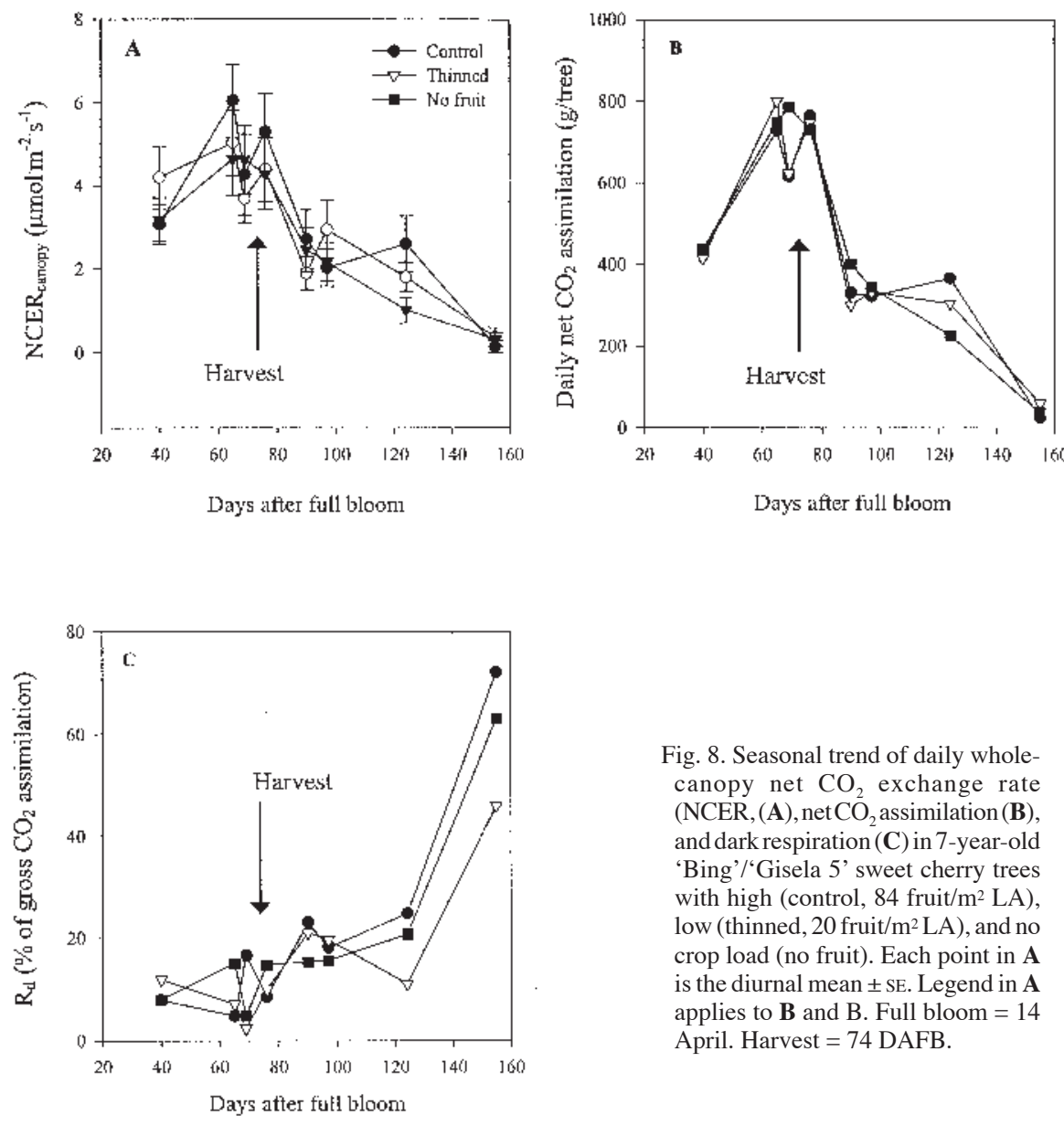

Fig. 8. Seasonal trend of daily wholecanopy net $\mathrm{CO}_{2}$ exchange rate (NCER, (A), net $\mathrm{CO}_{2}$ assimilation $(\mathbf{B})$, and dark respiration $(\mathbf{C})$ in 7-year-old 'Bing'/'Gisela 5' sweet cherry trees with high (control, 84 fruit $/ \mathrm{m}^{2} \mathrm{LA}$ ), low (thinned, 20 fruit $/ \mathrm{m}^{2} \mathrm{LA}$ ), and no crop load (no fruit). Each point in $\mathbf{A}$ is the diurnal mean \pm SE. Legend in $\mathbf{A}$ applies to $\mathbf{B}$ and B. Full bloom $=14$ April. Harvest $=74$ DAFB .
2.56 for $\mathrm{C}, 2.29$ for $\mathrm{T}$, and $2.05 \mu \mathrm{mol} \cdot \mathrm{m}^{-2} \cdot \mathrm{s}^{-1}$ for NF. This agrees with earlier studies of cherry NCER $_{\text {leaf }}$ (Roper et al., 1988; Sams and Flore, 1983). Likewise, Chaumont et al. (1994) found that $\mathrm{NCER}_{\text {leaf }}$ was similar in defruited vs. fruiting grapevines. In contrast, the presence of fruit has been shown to increase efficiency of apple $\mathrm{NCER}_{\text {leaf }}$ and NCER $\mathrm{Nanopy}_{\text {compared to a }}$ nonfruiting condition (Giuliani et al., 1997a, 1997b; Wünsche et al., 2000).

The lack of a significant F:LA effect on $\mathrm{NCER}_{\text {canopy }}$ likely was due to the overriding effect of competing sinks. Convergence of vegetative and reproductive sink activity during the preharvest interval appears to create a source-limited condition (i.e., biomass gain is limited by assimilate supply) because the presence of fruit on $\mathrm{C}$ and $\mathrm{T}$ trees did not increase NCER $_{\text {canopy }}$, compared to NF. However, inference of source-limiting conditions based on the relationship between F:LA and organ growth may be misleading, particularly without determining the relative contributions from carbohydrate and mineral storage tissues. Delineation of the spatial and temporal variability in carbon partitioning among and within spurs and shoots is needed to identify inter-organ competition for assimilates during critical stages of fruit growth.

The difference between $\mathrm{CO}_{2}$ assimilated during the day and that lost during the night (i.e., net assimilation: $\mathrm{NCER}_{\text {canopy }} \times$ canopy LA) provides an effective estimate of wholeHowever, in July, NCER canopy was $23 \%$ higher than NCER $_{\text {leaf }}$. This may reflect a decline in photosynthetic efficiency of aging leaves because $\mathrm{NCER}_{\text {leaf }}$ was measured on fully expanded spur and shoot leaves, whereas NCER canopy measurements integrated all leaf populations, including recently expanded leaves which exhibit greater $\mathrm{CO}_{2}$ exchange rates (Roper and Kennedy, 1986; Sams and Flore, 1982).

The maximum daily NCER $\mathrm{Nanopy}_{\text {of }} 6.1 \mu \mathrm{mol} \cdot \mathrm{m}^{-2} \cdot \mathrm{s}^{-1}$ for nonthinned cherry trees at 64 DAFB is comparable to that of 6.7 $\mu \mathrm{mol} \cdot \mathrm{m}^{-2} \cdot \mathrm{s}^{-1}$ at $181 \mathrm{DAFB}$ for heavily-cropped apple canopies (Wünsche et al., 2000), and about $45 \%$ greater than the 4.2 $\mu \mathrm{mol} \cdot \mathrm{m}^{-2} \cdot \mathrm{s}^{-1}$ recorded in August and September for apple (Wibbe et al., 1993). Previous reports comparing cherry and apple have shown similarities for $\mathrm{NCER}_{\text {leaf }}$ values (Flore and Lakso, 1989). On a canopy basis, dissimilarities in environmental conditions during measurement, canopy source-sink relations, canopy architecture, and/or whole-canopy system design may account for differences in NCER. Despite similar NCER canopy , maximum apple canopy assimilation of $\approx 131 \mathrm{~g} /$ tree at 109 DAFB (Wünsche et al., 2000) was much lower than the $801 \mathrm{~g} /$ tree at 64 DAFB (Fig. 8B) reported herein, due to greater LA on the cherry tree (e.g., $\approx 40$ $\mathrm{m}^{2}$ vs. $10 \mathrm{~m}^{2}$ in Wünsche et al., 2000). Moreover, this suggests that the free-standing standard sweet cherry canopy architecture was particularly effective by yielding a similar daily NCER and 6-fold greater canopy assimilation with 4-fold greater LA.

Seasonal NCER $\mathrm{c}_{\text {canopy }}$ was unaffected by F:LA, averaging 3.28 $\mu \mathrm{mol} \cdot \mathrm{m}^{-2} \cdot \mathrm{s}^{-1}$ for $\mathrm{C}, 3.05 \mu \mathrm{mol} \cdot \mathrm{m}^{-2} \cdot \mathrm{s}^{-1}$ for $\mathrm{T}$, and $2.85 \mu \mathrm{mol} \cdot \mathrm{m}^{-2} \cdot \mathrm{s}^{-1}$ for NF. Preharvest mean NCER canopy $_{\text {was }} 4.46$ for C, 4.31 for $\mathrm{T}$, and $4.15 \mu \mathrm{mol} \cdot \mathrm{m}^{-2} \cdot \mathrm{s}^{-1}$ for $\mathrm{NF}$, while postharvest means were tree carbohydrate supply, which is particularly useful for modeling growth, partitioning, and yield (Grossman and DeJong, 1994). Seasonally, the trend of net assimilation was similar to that of the $\mathrm{NCER}_{\text {canopy }}$, although treatment differences were less pronounced at each date (Fig. $8 \mathrm{~B}$ ). The seasonal average daily net $\mathrm{CO}_{2}$ assimilation per tree was 448 for $\mathrm{C}, 448$ for $\mathrm{T}$, and 464 $\mathrm{g} /$ day for NF. Maximum net assimilation occurred at $64 \mathrm{DAFB}$, irrespective of crop load. Canopy net assimilation was higher preharvest than postharvest: $592 \mathrm{vs.} 361 \mathrm{~g} \cdot \mathrm{d}^{-1}$ for $\mathrm{C}, 613 \mathrm{vs.} 349$ $\mathrm{g} \cdot \mathrm{d}^{-1}$ for $\mathrm{T}$, and $657 \mathrm{vs.} 348 \mathrm{~g} \cdot \mathrm{d}^{-1}$ for NF. Crop load did not affect relative dark respiration (Fig. 8C). This supports the contention that many active, nonfruiting sinks exist in sweet cherry canopies (Roper et al., 1988). Absolute respiratory carbon losses did not change appreciably throughout the season, while daily $\mathrm{CO}_{2}$ fixation declined. Therefore, nighttime respiratory losses of $\mathrm{CO}_{2}$ accounted for a greater percentage of daily $\mathrm{CO}_{2}$ fixation toward the end of the growing season (e.g., $60 \%$ by 153 DAFB) (Fig. $8 \mathrm{C})$. In contrast, fruiting in apple increased daily carbon gain and nighttime carbon loss compared to nonfruiting trees (Wibbe et al., 1993). Wünsche et al. (2000) also reported greater $\mathrm{CO}_{2}$ assimilation and dark respiration in fruiting apple canopies compared to nonfruiting apple canopies before harvest.

DyNAMIC CANOPY FRUITING EFFECTS. In fruiting sweet cherry trees, there is intense and dynamic competition for assimilates during the preharvest period due to the convergence of vegetative and reproductive sink activity. Fruit growth may compete with expanding leaves, extension and secondary growth of shoots, trunk, and roots, as well as buds and reserve tissues, for limited carbohydrate and mineral resources. Kappel (1991) showed that 
the greatest proportion of above-ground dry matter in 'Lambert' sweet cherry trees was partitioned annually to wood, the least to fruit, and current seasonal growth of shoots was identified as a greater sink than fruit. In contrast, assimilate partitioning to fruit accounts for the greatest annual dry weight increment in peach (Miller and Walsh, 1988) and apple (Buwalda and Lenz, 1992).

This competition is a function of tree sink-source relations and therefore is also related to the various assimilate sources from different leaf populations and storage reserves. In this study, high F:LA increased sink demand while concomitantly reducing canopy supply capacity (Fig. 6A). If gross canopy LA becomes limiting at $\approx 200 \mathrm{~cm}^{2} /$ fruit (Fig. 3D-F), and the average LA/spur leaf and LA/shoot leaf on the experimental trees was 27 and 54 $\mathrm{cm}^{2}$, respectively, then $\approx 7.4$ spur leaves or 3.8 shoot leaves per fruit would be needed to produce fruit of good quality. This illustrates the usual F:LA imbalance within spurs that led Roper et al. (1987) to conclude that sweet cherry spur leaves on a high-vigor rootstock like Mazzard do not have the capacity to support optimal fruit growth. Fruiting spurs of 'Bing' trees generally have six to nine leaves while fruiting on dwarfing rootstocks like 'Gisela 5' can produce up to 30 times higher crop loads per spur (Webster and Schmidt, 1996) than 'Mazzard', leading to even greater LA/ spur insufficiency. In this study, the T trees yielded good quality fruit in 2000 with an average of less than one fruit/spur; in this experimental case, as our derived relationships would predict, spur leaves alone were, at best, adequate for good fruit size. However, the experimental crop load was clearly below that for reasonable commercial yields.

An estimate of balanced cropping (i.e., yield vs. quality) for mature 'Bing'/'Gisela 5' cherry trees can be developed from the relationship between crop load and fruit quality (Fig. 3). The F:LA of $84 \mathrm{~m}^{2}$ resulted in high yields $\left(20.8 \mathrm{t} \cdot \mathrm{ha}^{-1}\right.$ at 340 trees/acre $)$ of poor quality fruit, while the F:LA of $20 \mathrm{~m}^{2}$ resulted in low yields (6.4 $\mathrm{t} / \mathrm{ha}$ ) of excellent quality fruit. Based on the regression relationships between F:LA and fruit quality, for a 7-year-old tree with $\mathrm{LA}_{\text {tree }}=$ $40 \mathrm{~m}^{2}, \mathrm{~F}$ :LA would need to be $\approx 41$ (i.e., 1640 fruit/tree, assuming mean fruit mass $=8.9 \mathrm{~g})$ to match current mean yields $(\approx 12 \mathrm{t} / \mathrm{ha})$ of Washington sweet cherry growers. This translates to a minimum LA:F of $244 \mathrm{~cm}^{2}$ at which fruit growth would be predicted to not be limited by assimilate supply (Fig. 3). Furthermore, our results suggest that reductions in crop load would promote floral initiation for the following year (Fig. 2), possibly translating into more fruit in the subsequent season than expected.

\section{Conclusions}

Canopy F:LAaffected fruit quality, shoot length, flower bud initiation, LA/spur, and tree radial expansion. However, NCER ${ }_{\text {canopy }}$ was not significantly affected. Reduced fruit quality at high F:LA was due to competition for assimilates among adjacent fruit exacerbated by reduced LA/spur and shoot length, critical components for assimilate supply. Consequently, a balance exists between fruit quality, yield, and LA in sweet cherry canopies, particularly on dwarfing rootstocks. The hierarchy of developmental sensitivity to high F:LA for above-ground organs and growth processes in 'Bing'/'Gisela 5' sweet cherry trees appears to be: trunk expansion $>$ fruit soluble solids (Stage III) $>$ fruit growth (Stage III) $>$ LA/spur $>$ shoot elongation $>$ fruit growth (Stages I and II) $>$ LA/shoot. Fruit thinning will be critical for balancing canopy F:LA and improving sweet cherry fruit quality on dwarfing rootstocks.

The commercial adoption of such rootstocks may depend on the future development of practical thinning strategies to improve canopy source-sink relations, particularly blossom or fruit thinning practices that do not remove leaves. Manually removing dormant reproductive buds is not practical commercially, although the mechanical removal of entire fruiting spurs (extinction) is advocated in France (P.E. Lauri, personal communication) as a thinning strategy. Potential blossom thinning agents are also being investigated(R. Núñez-Elisea, personal communication; Whiting, unpublished), as well as pruning strategies that focus more on balancing crop load than on controlling vigor (Lang, 2001). The results of this study serve as a foundation upon which potential thinning strategies can be rationalized and quantified.

\section{Literature Cited}

Ben-Mimoun, M., J.J. Longuenesse and M. Genard. 1996. Pmax as related to leaf:fruit ratio and fruit assimilate demand in peach. J. Hort. Sci. 71:767-775.

Buwalda, J.G. and F. Lenz. 1992. Effects of cropping nutrition and water supply on accumulation and distribution of biomass and nutrients for apple trees on M9 root systems. Physiol. Plant. 84:21-28.

Chalmers, D.J., R.L. Canterford, P.H. Jerie, T.R. Jones, and T.D. Ugalde. 1975. Photosynthesis in relation to growth and distribution of fruit in peach trees. Austral. J. Plant Physiol. 2:635-645.

Chaumont, M., J. Morot-Gaudry, and C.H. Foyer. 1994. Seasonal and diurnal changes in photosynthesis and carbon partitioning in Vitis vinifera leaves in vines with and without fruit. J. Expt. Bot. 45:1235-1243.

DeJong, T.M. 1986. Fruit effects on photosynthesis in Prunus persica. Physiol. Plant. 66:149-153.

DeJong, T.M. and Y.L. Grossman. 1994. A supply and demand approach to modeling annual reproductive and vegetative growth of deciduous fruit trees. HortScience 29:1435-1442.

Edin, M., A. Garcin, J. Lichou, and J.M. Jourdain. 1996. Influence of dwarfing cherry rootstocks on fruit production. Acta Hort. 410: 239-245.

Farley, A.J. 1923. Factors that influence the effectiveness of peach thinning. Proc. Amer. Soc. Hort. Sci. 20:145-151.

Flore, J.A. and A.N. Lakso. 1989. Environmental and physiological regulation of photosynthesis in fruit crops. Hort. Rev. 11:111-157.

Flore, J.A. and D.R. Layne. 1999. Photoassimilate production and distribution in cherry. HortScience 34:1015-1019.

Forshey, C.G. and D.C. Elfving. 1989. The relationship between vegetative growth and fruiting in apple trees. Hort. Rev. 11:229-287.

Giaquinta, R. 1978. Source and sink leaf metabolism in relation to phloem translocation. Plant Physiol. 61:380-385.

Giuliani, R, L. Corelli-Grappadelli, and E. Magnanini. 1997a. Effects of crop load on apple photosynthetic responses and yield. Act. Hort. 451:303-311.

Giuliani, R., F. Nerozzi, E. Magnanini, and L. Corelli-Grappadelli. 1997b. Influence of environmental and plant factors on canopy photosynthesis and transpiration of apple trees. Tree Physiol. 17:637-645.

Greene, D.W., W.R. Autio, and P. Miller. 1990. Thinning activity of benzyladenine on several apple cultivars. J. Amer. Soc. Hort. Sci. 115:394-400.

Grossman, Y.L. and T.M. DeJong. 1994. PEACH: A simulation model of reproductive and vegetative growth in peach trees. Tree Physiol. 14: 329-345.

Gucci, R., L. Corelli Grappadelli, S. Tustin, and G. Ravaglia. 1995. The effect of defruiting at different stages of fruit development of leaf photosynthesis of 'Golden Delicious' apple. Tree Physiol. 15:35-40.

Guimond, C.M., P.K. Andrews, and G.A. Lang. 1998. Scanning electron microscopy of floral initiation in sweet cherry. J. Amer. Soc. Hort. Sci. 123:509-512.

Haller, M.H. and J.R. Magness. 1925. The relation of leaf area to the growth and composition of apples. Proc. Amer. Soc. Hort Sci. 22: 189-196.

Hutton, R.J. 1992. Improving fruit size and packout of late Valencia 
oranges with ethephon fruit-thinning sprays. Austral. J. Expt. Agr 32:753-758.

Kappel, F. 1991. Partitioning of above-ground dry matter in 'Lambert' sweet cherry trees with or without fruit. J. Amer. Soc. Hort. Sci. 116: 201-205.

Kennedy, R.A. and D. Johnson.. 1981. Changes in photosynthetic characteristics during leaf development in apple. Photosyn. Res. 2: 213-223.

Lang, G.A. 2000. Precocious, dwarfing, and productive - how will new cherry rootstocks impact the sweet cherry industry? HortTechnology 10:719-725.

Lang, G.A. 2001. Critical concepts for sweet cherry training systems. Compact Fruit Tree 34:70-73.

Lang, G.A. and D.R. Ophardt. 2000. Intensive crop regulation strategies in sweet cherries. Acta Hort. 514:227-233.

Long, S.P. and J.-E. Hallgren. 1985. Measurement of $\mathrm{CO}_{2}$ assimilation by plants in the field and the laboratory, p. 62-94. In: J. Coombs, D.O. Hall, S.P. Long, and J.M.O. Scurlock (eds.). Techniques in bioproductivity and photosynthesis. Pergamon Press.

Looney, N.E. 1989. Effects of crop reduction, gibberellin sprays and summer pruning on vegetative growth, yield and quality of sweet cherries, p. 39-50. In: C.J. Wright (ed.). Manipulation of fruiting. Butterworths, London.

Maggs, D.H. 1963. The reduction in growth of apple trees brought about by fruiting. J. Hort. Sci. 39:85-94.

Miller, A.N. and C.S. Walsh. 1988. Growth and seasonal partitioning of dry matter in eight-year-old 'Loring' peach trees. J. Amer.Soc. Hort. Sci. 113:309-314.

Palmer, J.W., R. Giuliani, and H.M. Adams. 1997. Effect of crop load on fruiting and leaf photosynthesis of 'Braeburn'/M.26 apple trees. Tree Physiol. 17:741-746.

Perry R., G. Lang, R. Andersen, L. Anderson, A. Azarenko, T. Facteau, D. Ferree, A. Gaus, F. Kappel, F. Morrison, C. Rom, T. Roper, S. Southwick, G. Tehrani, and C. Walsh. 1997. Performance of the NC-140 cherry rootstock trials in North America. Acta Hort. 451:225-229.

Poni, S., E. Magnanini, and B. Rebucci. 1997. An automated chamber system for measurements of whole-vine gas exchange. HortScience 32:64-67.

Proebsting, E.L. and H.H. Mills. 1981. Effects of season and crop load on maturity characteristics of 'Bing' cherry. J. Amer. Soc. Hort. Sci. 106:144-146.

Roper, T.R., J.D. Keller, W.H. Loescher, and C.R. Rom. 1988. Photosynthesis and carbohydrate partitioning in sweet cherry: Fruiting effects. Physiol. Plant. 72:42-47.

Roper, T.R. and R. Kennedy. 1986. Photosynthetic characteristics during leaf development in 'Bing' sweet cherry. J. Amer. Soc. Hort. Sci. 116: 938-941.
Roper, T.R. and W.H. Loescher. 1987. Relationships between leaf area per fruit and fruit quality in 'Bing' sweet cherry. HortScience 22: $1273-1276$

Roper, T.R., W.H. Loescher, J. Keller, and C.R. Rom. 1987. Sources of photosynthate for fruit growth in 'Bing' sweet cherry. J. Amer. Soc. Hort. Sci. 112:808-812.

Ryugo, K. 1986. Promotion and inhibition of flower initiation and fruit set by plant manipulation and hormones, a review. Acta Hort. 179: 301-301.

Sams, C.E. and J.A. Flore. 1982. The influence of age, position, and environmental variables on net photosynthetic rate of sour cherry leaves. J. Amer. Soc. Hort. Sci. 107:339-344.

Sams, C.E. and J.A. Flore. 1983. Net photosynthetic rate of sour cherry (Prunus cerasus L. 'Montmorency') during the growing season with particular reference to fruiting. Photosyn. Res. 4:307-316.

Spayd, S.E., E.L. Proebsting, and L.D. Hayrynen. 1986. Influence of crop load and maturity of quality and susceptibility to bruising of 'Bing' sweet cherries. J. Amer. Soc. Hort. Sci. 111:678-682.

Weaver, R.J. and R.M. Pool. 1971. Chemical thinning of grape clusters (Vitis vinifera L.). Vitis 10:201-209.

Webster, A.D. and H. Schmidt. 1996. Rootstocks for sweet and sour cherries, p. 127-163. In: A.D. Webster and N.E. Looney (eds.). Cherries: Crop physiology, production and uses. CAB Intl., Wallingford, Oxon, U.K.

Weinberger, J.H. 1931. The relation of leaf area to size and quality of peaches. Proc. Amer. Soc. Hort. Sci. 28:18-22.

Wells, J.M. and M. Bukovac. 1978. Effect of fruit thinning on size and quality of 'Stanley' plum (Prunus domestica L.). J. Amer. Soc. Hort. Sci. 103:612-616.

Whiting, M.D. 2001. Whole canopy source-sink relations and fruit quality in 'Bing' sweet cherry trees on a dwarfing, precocious rootstock. PhD diss. Wash. State Univ., Pullman.

Whiting, M.D. and G.A. Lang. 2001. Canopy architecture and cuvette flow patterns influence whole-canopy net $\mathrm{CO}_{2}$ exchange and temperature in sweet cherry. HortScience 36:691-698.

Wibbe, M.L., M.M. Blanke, and F. Lenz. 1993. Effect of fruiting on carbon budgets of apple tree canopies. Trees 8:56-60.

Wünsche, J.N., A.N. Lakso, and T.L. Robinson. 1995. Comparison of four methods for estimating total light interception by apple trees of varying forms. HortScience 30:272-276.

Wünsche, J.N. and J.W. Palmer. 1997. Effects of fruiting on seasonal leaf and whole-canopy carbon dioxide exchange of apple. Acta Hort. 451:295-301.

Wünsche, J.N., J.W. Palmer, and D.H. Greer. 2000. Effects of crop load on fruiting and gas-exchange characteristics of 'Braeburn'/M.26 apple trees at full canopy. J. Amer. Soc. Hort. Sci. 125:93-99. 